\title{
Evaluation of Corrosion Detection in Reinforced Concrete using Infrared Thermography
}

\author{
J.Ashok Kumar ${ }^{1}$, R. Preetha ${ }^{1}$, C.Sundaramurthy ${ }^{1}$, M.Menaka ${ }^{2}$, Sharath.D ${ }^{2}$, Ajay \\ Rawat ${ }^{3}$, B.Venkatraman ${ }^{3}$
}

1. Civil Engineering Group, IGCAR, Kalpakkam-603102

2. Quality Assurance Division, IGCAR, Kalpakkam-603102

3. Radiological Safety Division, IGCAR, Kalpakkam-603102

\begin{abstract}
Corrosion of reinforcing steel and other embedded metals is the leading cause of deterioration in reinforced concrete strucutres. The steel corrosion products ,occupies a greater volume than the steel. This expansion creates tensile stresses in the concrete, which can eventually cause cracking, delamination, and spalling of cover concrete ,leading to further degradation. Corrosion of steel in concrete is an electrochemical process, which takes place as a result of the formation of a corrosion cell. Exposure of reinforced concrete to chloride ions in an aggressive environment is the primary cause of premature corrosion of steel reinforcement. Corrosion loss consumes considerable portion of the budget of the country by way of either restoration measures or reconstruction. By monitoring the structures for corrosion performance and taking suitable measures at the appropriate time could effect enormous saving. This paper studies application of lock in thermography for detection of corrosion in reinforced bars and developed crack at various depth due to the accelerated corrosion in reinforced bar.
\end{abstract}

